\title{
特集 病院総合医セミナー2014
}

\section{$\mathrm{ER}$ 外来指導法 \\ 一プライマリケア最前線の ER で何をどう教えるか？}

\section{林寛之}

福井大学医学部附属病院 総合診療部

\section{ER の特徵}

ERの特徴は時間的制約があること，検査が限られ ていること，患者さんとの良好な医師一患者関係をす ぐには構築しづらい環境にあること, 体力的に夜間の 診療はきついだけでなく頭そのものの回転が鈍ってし まうこと，トイレに行きたくても行けないこと，カッ プラーメンが伸びてしまってとても食べられない状況 になってしまい易いことなどなど様々な障壁が待ち構 えている.

一方, 若手医師であっても初診から診断をつけ, 判 断ミスが患者さんの予後に直結してしまうこと, 患者 さんは真夜中でも背に腹は代えられず若造（失礼！) であっても素直に診察を受けるしかないこと，などか ら若手医師が堂々と最前線に立ち, 診断学治療学を駆 使できる絶好の教育の場である.

一般的な診断学のアプローチである「病歴 $\rightarrow$ 身体所 見 $\rightarrow$ 鑑別診断 $\rightarrow$ 検査 $\rightarrow$ 治療」という方式は残念ながら できない環境でもある。診断がつかない状況であって も処置をしつつ，手を出して行かないといけない．診 断と治療が同時並行で行われるのも ER の醍醐味であ るが，上級医は若手医師を教える十分な時間もとれな いところに問題がある.

ER での診断はむしろ「Sick or not sick $\rightarrow$ バイタル サインと $\mathrm{ABC} \rightarrow$ 最悪の疾患を常に予想する $\rightarrow$ Disposition (帰宅か入院か)」という判断が求められてくる.

\section{体系だった ER 教育}

ER で教えるべきは(1)知識，(2)技術，(3)プロフェッ ショナリズムであり，それも時間を意識したリズムに 乗らなくてはならない. 風邪や莀麻疹, 鼻に詰めた $\mathrm{BB}$ 弾の除去や創縫合，骨折診断のみならず，心肺停 止に多発外傷，アナフィラキシーショックに敗血症を リズムに乗って対応していく術を教える必要がある。

\section{1 ) On the job training}

(1)重症患者のアプローチ

ER では重症患者を診断がつかなくても対処しなけ

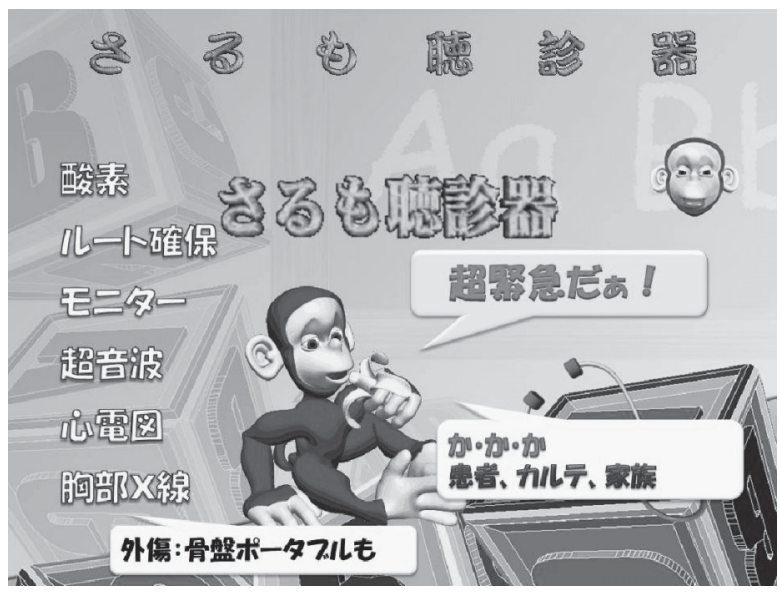

図 1 ショック患者のアプローチ Dr. 林の「さるも聴診器」

ればならない. 特に患者さんが心肺停止になる前の ショックの対応は迅速に救命できる原因を探し出しつ つ処置を進める必要がある。ここで Dr. 林の「さるも 聴診器！」を若手医師にすり込んでいただければと思 う（図 1）. 患者さんを目の前から離さないで蘇生処 置をしつつ，原因検索する優れ技であり，病棟での急 変でも使える.

さ: 酸素投与
る : ルート確保
も : モニター (ECG, SpO2)
聴 : 超音波 Pump/Tank/Pipe
診 : 12 誘導心電図
器 : 胸部X線ポータブル（外傷の時は骨盤正面 X 線ポー
$\quad$ タブルも追加）

上記検査と治療を同時進行で行いつつ救命していく 手順を体に染み込ませたい。超音波も単に腹腔内の工 コーフリースペースを見るにとどまらず，きちんと体 系立てて短時間に利用できるようになりたい。ショッ ク患者では特に Pump（心臓：心収縮，右室拡大，心 囊液貯留), Tank（腹腔・胸腔エコーフリースペー ス, 下大静脈), Pipe (大動脈, 大腿 - 膝窩静脈）を チェックしつつ原因検索を行う。超音波手技に慣れて いれば, 気胸の有無, 肺水腫の有無なども超音波でア プローチ可能となる. 
救急だからと言って単純に検査さえすればいい訳で はなく，やはり病歴と身体所見がものを言う。そこで 「3つの『か』: 患者 (診察), 家族 (状況), カルテ (既 往歴)」をチェックして患者背景, ショックに至った 過程を推測するのである.

\section{(2)軽症〜中等症患者のアプローチ}

軽症〜中等症の救急対応は現場ですり込むように教 えていく.やはり common is commonであり, 奇を てらったような疾患などシマウマ探しを ER でしては ならない，事前確率の低い検査の絨廹爆撃程無駄なも のはない. どんなに机上の勉強会やセミナーをしょう とも，血の通った患者さんの様々な顔を帱見しながら 行う医療はひと味もふた味も違う。臨床の答えは臨床 現場でしか得られない.

その中で一見元気そうに見えて，実は重症と言う 「隠れ重症」は $0.2 \sim 0.7 \%$ の割合で遭遇する。 その隠 れ重症を見逃さないためにも, 必ず最悪のシナリオを 常に鑑別に挙げる訓練を行う必要がある．そのために は system 1, つまり直観力, スナップ診断, パター ン認識も必要になる。初学者が直観力をすぐに身につ けることは難しいが，隠れ重症のパターン認識力を養 うのには非常に有用である. 特に生命の脅かす病態の 認識においては無駄に時間を浪費することがあっては ならない.

実際には重症疾患だけを考えるのでは臨床では使い 物にならないので, 重症疾患 3 つ, よくある疾患 3 つ ずつぐらいを考える様に指導していく，余裕があれば 治しうる疾患も鑑別に挙げられると良い。

(3) ER 外来短時間指導法 5 micro-skill

ERの時間的制約の中で是非行ってほしいのが，5 micro skill である（図2). 限られた時間の中で悠長 にコンサルトを受ける余裕はないことが多い，その際 には，まとまりのないコンサルトに時間をかけること なく, 若手医師の思考過程を紐解くような質問力が有 効になってくる.つい「あれやったか，これをしてお け」と自分の思考過程を押し付ける指導法になってい ないだろうか，それでは若手医師は自分で考える機会 を失ってしまう。

まず, 診断名, 鑑別診断名をあげてもらう 次にそ の根拠となる病歴と身体所見を聞く 次にいい点を褒 める 改善すべき点を否定的（negative）ではなく, 建設的 (constructive) にアドバイスする $\rightarrow$ 最後に教 育ポイントをひとつに絞って教える。この手順であれ

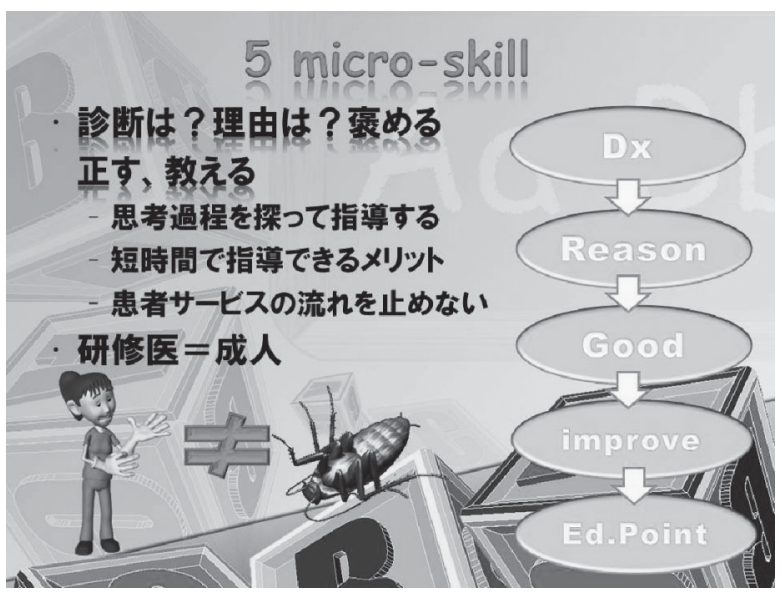

図 2 ERにおける短時間指導法 5 microskill

ば 2-3 分で ER 外来指導ができる. 毎回必ずいい点を ほめることを前提に話を聞かないと，いい点を探し出 せないので，そのつもりで話を聞く姿勢が必要にな る。また教育内容が多すぎてもいけない. 若手医師が 受け取れるだけの内容を短時間で的を絞ることが重要 だ，ERで長々と教育するのは，上級医の自己満足で しかないのでご注意を．患者サービスの流れを止めな いのも重要である.

\section{2) Off the job training}

ER の特徵である重症疾患はテレビドラマでもない 限り, 毎日どかどかやってくるわけではない。たまに しか遭遇しない重症疾患だからこそ, スタンダードに 沿った治療ができるように，シミュレーション教育を しておくことは重要である.

また教育を充実させることで院内の初期研修医やコ メディカルとも協調して組織だって行動する事で一体 感が生まれ元気な研修施設になること請け合いだ。

ACLS (Advanced Cardiac Life Support), ICLS (Immediate Cardiac Life Support), JATEC (Japan Advanced Trauma Evaluation and Care), PALS (Pediatric Advanced Life Support), APLS (Advanced Pediatric Life Support), BLSO (Basic Life Support in Obstetrics), ALSO (Advanced Life Support in Obstetrics), T\&A (Triage \& Assessment), PIPC (Psychiatry in Primary Care), HAPPY (History taking And Physical examination for Pediatric Young doctor) などなど, 略語が乱立しているよう にも見えるが, 若い人をその気にさせるには奉仕教育 も必要だ.

昔気質職人は背中で語ればよかったが, 今の時代は 
「いい指導医は良く教えてくれる」, いい指導医は demonstration してくれる, 更に素晴らしい mentor はやる気を起こしてくれる，若手医師が自分で進んで 勉強する器質ができれば, 上級医の老後も安泰だ (?).

\section{プロフェッショナリズム教育のチャンス}

様々な緊急性の多科に渡る疾患のみならず，多彩な 背景を持つ患者が訪れるのが $\mathrm{ER}$ の醍醐味ともいえ る.「救急」とは自己申告制であり，医学的に本当に 「救急」でないと ER を訪れてはいけないと言うこと はない．患者さんが「自分は救急だ！」と思えば来院 して良いとわりきらないと，医療者の心もギスギスし たものになってしまう。医学部で 6 年も觔強し, 初 期・後期研修を終えてもなお，隠れ救急疾患にはプロ でも騙される訳だから，素人さんの自己判断で救急で あることを見抜けるはずもないではないか. 一見, 元 気そうに歩いてやってくる救急患者の中には 0.2 $0.7 \%$ 割合で隠れ重症救急がやってくることを是非 とも若手医師には伝えたい，そのためにも，一見軽症 そうにみえても怪訝に思わず，全開の笑みで迎える心 優しき上級医を演じないといけないのが ERのもうひ とつの醍醐味だ。「いい人」のふりをしているうちに 本当に「いい人」になってしまうのが, 草食系 $\mathrm{ER} の$ いいところ.

従って, ER では(1)見るからに重症のマネージメン 卜，(2)隠れ重症の見抜き方，(3)軽症～中等症のマネー ジメント，(4)わけあり症例までをきちんと若手医師に 教えないといけない,わけありとは, 虐待, 犯罪, 社 会的弱者など様々な理由があり夜間受診してくる場合 であり, 単純な診断学では語れない人生の機微を垣間
見る機会だ．つまり救急の知識・技術のみならずプロ フェッショナリズムも教えることができるチャンスが ある，真夜中にやってくる隠れ重症，酔っ払い，暴 力, 社会的問題などは医療の神様があなたを試してい るに他ならない。，心が折れそうになったら，チラッと 横を見てみよう，あなたがどうこの局面をにこやかに 余裕をもって乗り切るかを若手医師はカーテン越しに 親いているのが見えるだろう。ここでプロフェッショ ナリズムを見せるチャンスと思えたらしめたもの!あ なた自身もロールモデルとして若手医師との違いを見 せるチャンスをもらえたっていうことだ. 社会的地位 や論文の数などはロールモデルとしてはまったく必要 ないむしろ愛のある患者対応と臨床力が重要なの だ。

医師として「怒らない選択」はすべての医療者に通 じる最重要点である．ERでは研修医の安全・安心を 確保しつつ，笑顔を忘れず，研修医には元気な指導医 の姿を見てもらう様にしたいものである，世の中「や られたら倍返しだ」ともてはやされたが，現場では「や られたら，倍やられた」ふりをする方がいい，局地戦 で勝っても大局で負けては意味が無い. 患者さんのマ ネージメントが最適になるように, 患者さんのために 頭を下げることができることが上級医として大事な資 質でもある。「実ほど首（こうべ）を垂れる稲穂かな」 とはプライマリケア医のプライドなのかも.

\section{文 献}

1) Wright SM1, Kern DE, Kolodner K, et al : Attributes of excellent attending-physician role models. N Engl J Med. 1998, 339 (27) : 1986-1993 